\title{
Study on Development and Quality Evaluation of Turnovers Produced from Bambara Bean and Wheat Flour Blends
}

Brenyah Florence $^{1 *}$, Sitsofe Kwakudua Ruth ${ }^{2}$, Kwaatemaa Florence ${ }^{3}$

\author{
${ }^{1}$ Department of Biochemistry and Biotechnology, Kwame Nkrumah University of Science and Technology, Kumasi-Ghana \\ ${ }^{2}$ Tutor, Home Economics Department, Presbyterian College of Education Kibi,-Ghana \\ ${ }^{3}$ Tutor, Home Economics Department, Berekum College of Education, Berekum, Ghana
}

\section{Article History \\ Received: 07.12.2020 \\ Accepted: 18.12 .2020 \\ Published: 23.12.2020}

Journal homepage:

https://www.easpublisher.com

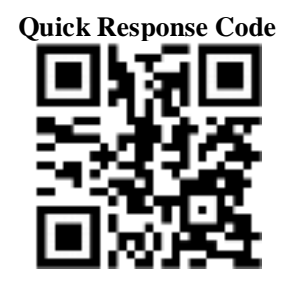

Abstract: The aim of the study was to prepare turnovers from Bambara beans and wheat flour blends. Three different samples of turnovers were produced and coded as sample A (control) containing 100\% wheat flour, sample 'B' $70 \%$ wheat flour and $30 \%$ bambara bean flour, while sample $\mathrm{C}$ was prepared from $50 \%$ wheat flour and $50 \%$ bambara bean flour. The results of proximate composition of the various turnovers showed increasing level of moisture $18.34 \pm 19.33 \%$, Ash $1.23 \pm 2.67 \%$, fat $30.41 \pm 34.75 \%$, protein $8.11 \pm 10.59 \%$, and carbohydrate $33.65 \pm 40.62 \%$. A panel of fifty (50) untrained judges was involved for the Sensory Analysis based on a hedonic scale of 1-9. Data obtained were subjected to Analysis of variance (ANOVA) and differences in means were computed using Least Significant Difference (LSD) test at $95 \%$ confidence interval. The sensory properties of the turnover samples showed that the composite samples were statistically $(\mathrm{p}<0.05)$ different from the control in terms of aroma, appearance, taste, colour and overall acceptability. The finding reveals that turnover made with composite sample B (70\%wheat flour and 30\% Bambara beans flour) was preferred by the respondents.

Keywords: Bambara beans, wheat flour, turnovers, proximate composition, sensory evaluation, composite flour.

Copyright (C) 2020 The Author(s): This is an open-access article distributed under the terms of the Creative Commons Attribution 4.0 International License (CC BY-NC 4.0) which permits unrestricted use, distribution, and reproduction in any medium for non-commercial use provided the original author and source are credited.

\section{INTRODUCTION}

Bambara bean (Vigna underground L.) has been used as composite flour for preparing healthy products. Study conducted by [1] shows that the seed contains $20-26 \%$ protein as well as $6.6 \%$ lysine and makes a magnificent source of proteins in the diet of humankind. Bambara bean can be used to prepare different delicacies in West Africa.

In Ghana, Bambara seeds are processed into flour, which is generally added to maize to enhance the nutritional content [2]. An assortment of pastry products and porridge can be produced using Bambara beans flour [3]. According to [4], Bambara seeds are simmered and pounded with palm kernel, and at times processed into flour for making bean cakes in southern Nigeria. Bambara bean seeds contain $63 \%$ carbohydrate, $19 \%$ protein and $6.5 \%$ oil [5].

The total energy estimation of Bambara bean is more noteworthy than that of other regular legumes, for example, cowpea, lentil (Lensesculenta) and pigeonpea (Cajanus cajan) [6]. Bambara beans are a decent wellspring of fiber, calcium, iron and potassium. The seed makes a total food, as it contains adequate amounts of proteins, starches, and lipids [7]. Flour can be produced using locally raw materials that are more nutritious, modest and promptly accessible [8]. The utilization of non-wheat flour blended with flour from high protein food sources for making tidbit and other pastry products in many developing countries might be legitimized from wholesome, practical, and agronomic points of view.

Wheat is the most basic solid food crop for about one-third of the people in the globe and offers more prominent calories and proteins to the body [9]. It is very nutritious, smooth to keep, transport and can be used to prepare various kinds of food. Wheat is considered a fantastic source of protein, minerals, Bvitamin and dietary fiber. The wholesome structure of wheat comprises protein, fat, starch, sugar, thiamin, riboflavin, niacin and folate [10]. Ghana in particular, the Wheat flour used for the making of baked goods are imported because the climate does not favour the cultivation of wheat and for that matter, making wheat flour very expensive[11].

There is therefore, a convincing need to build up a sufficient substitute for wheat flour in order to reduce the cost of importation. This substitute is accessible, modest and equipped for supplanting wheat 
in expediency. In this regard, about $75 \%$ of our foreign exchange is lost through importation of wheat, hence, the need for partial replacement of wheat with Bambara bean flour in the preparation of turnovers. The purpose this study was to produce quality turnovers from a blend of wheat and Bambara bean flours.

\section{Material ANd Methods}

\section{Processing of Bambara beans into flour}

Bambara bean flour was prepared using the method described by [1]. Bambara beans were cleaned manually to remove all foreign materials such as dust, dirt, small branches and immature seeds. The cleaned samples were sorted and soaked in water for $12 \mathrm{hrs}$; it was then dehulled and oven dried using Nasco oven, at $60{ }^{\circ} \mathrm{C}$ for $3 \mathrm{hrs}$ and finely ground to powder form with a high speed grinding machine and sieved using $500 \mu \mathrm{m}$ sieves to obtain fine flour.

\section{Sample Formulation}

Three different samples of turnovers were produced and coded as A, B, and C. The blends of Bambara bean flour and whole wheat flour were prepared in the ratio 100: $0,70: 30$, and 50:50. The flours were thoroughly mixed to obtain a homogenous blend. The samples were stored at the temperature $30 \pm$ $2{ }^{\circ} \mathrm{C}$ ) in air tight containers and labeled until needed for turnovers production.

Table-1: Formulation of ingredients

\begin{tabular}{|c|c|c|c|}
\hline INGREDIENTS & SAMPLE A & SAMPLE B & SAMPLE \\
\hline Wheat flour (g) & 200 & 70 & 50 \\
\hline Bambara beans flour & 0 & 30 & 50 \\
\hline Margarine (g) & $100 \mathrm{~g}$ & 100 & 100 \\
\hline Salt (g) & 1 & 1 & 1 \\
\hline Nutmeg (g) & 2 & 2 & 2 \\
\hline Canned beef $(\mathrm{g})$ & 100 & 100 & 100 \\
\hline Baking powder $(\mathrm{g})$ & 1 & 1 & 1 \\
\hline
\end{tabular}

Samples $\mathrm{A}=$ Wheat flour $100 \%, \mathrm{~B}=70 \%$ Wheat flour and 30\%Bambara beans, $\mathrm{C}=50 \%$ wheat flour and 50\%Bambara beans

\section{Method of preparing turnovers}

The Bambara beans and wheat flour turnover was prepared using the method described by [12] with minor changes. First of all, oven was preheated to 200 degrees and the baking sheets were greased. All ingredients were accurately weighed before and kept. Margarine was incorporated into the Flour and rubbed in until completely mixed. Baking powder together with salt was sifted into the mixture alongside nutmeg. These were mixed together in order to obtained a uniform texture. $150 \mathrm{ml}$ of water was incorporated into the mixture and to form soft dough. The dough was allow resting for 10 minutes to relax the gluten and afterwards, placed on a floured board and rolled to a desirable thickness. It was then cut into rectangle, filled with the canned beef, folded into a desirable shape, glazed and kept into the oven at $140 \mathrm{oC}$ for 20 minutes. After 20 minutes, the turnovers were checked and removed from the oven, allow cooling and packaged in a plain polythene bag for proximate analysis and sensory evaluation.

\section{Calculations}

$\%$ Moisture $(\mathrm{wt} / \mathrm{wt})=\mathrm{wt} \underline{\mathrm{H}_{2}} \underline{\mathrm{O} \text { in sample }} \times 100$ Wt of wet sample

$\%$ Moisture $(w t / w t)=\underline{w t ~ o f ~ w e t ~ s a m p l e-w t o f ~ d r y ~ s a m p l e ~} \times 100$ Wt of wet sample

$\%$ Total solids $(\mathrm{wt} / \mathrm{wt})=\frac{\mathrm{wt} \text { of dried sample }}{\text { Wt of wet sample }} \times 100$

Where $w \mathrm{t}=$ Weight of sample/spread
Proximate composition of wheat-Bambara turnovers Proximate analysis of samples was determined according to [13]. The samples were analysed for moisture content, ash, protein, fat, crude fibre.

\section{Moisture content and total solids: Oven Drying Method}

Five grams $(5 \mathrm{~g})$ of the sample was transferred to the previously dried and weighed dish. The Dish was placed in an oven and thermostatically controlled at 105 degrees for 5 hours. Dish was removed and placed in a desiccator to cool to room temperature and weighed. It was then dried again for 30 minutes, cooled down again and weighed. Drying, cooling and weighing were repeated until a constant weight was reached. (Alternatively, sample could be dried in a thermostatically controlled oven for at least 8 hours where a constant weight would be achieved). The determinations were duplicated and the average found [14] (Association of Official Analytical Chemists (2005). 


\section{Ash content}

$5 \mathrm{~g}$ sample was weighed into a tarred crucible and was pre-dried. Crucibles were placed in cool muffle furnace using tongs, gloves and protective eyewear. The crucibles Ignited for 2 hours at about 600 degrees Celsius. Muffle furnace was turned off and opened when temperature dropped to at least 250 degrees preferably lower. The door was carefully opened to avoid losing ash that may be fluffy. Safety tongs was used to transfer crucibles to a desiccator with a porcelain plate and desiccant. Desiccator was closed and allowed crucibles to cool prior to weighing.

\title{
Calculations
}

\author{
$\%$ Ash $=\underline{\text { wt of ash }} \times 100$ \\ Wt of sample \\ $\%$ Ash $=($ wt of crucible + ash $)-$ wt of empty crucible $\times 100$ \\ (wt of crucible+ sample) - wt of empty crucible
}

Where wt $=$ Weight of sample/spread

\section{Fat content: soxhlet extraction}

Previously dried (air oven at $100^{\circ} \mathrm{C}$ ) $250 \mathrm{ml}$ round bottom flask was weighed accurately. $5.0 \mathrm{~g}$ of dried sample to $22 \times 80 \mathrm{~mm}$ paper thimble or a folded filter paper was weighed. A small of cotton or glass wool was placed into the thimble to prevent loss of the sample. $150 \mathrm{ml}$ of petroleum spirit B.P $40-60^{\circ} \mathrm{C}$ was

$\%$ Fat $($ dry basis $)=\underline{\text { fat } / \text { oil collected } \times 100}$ Weight of sample

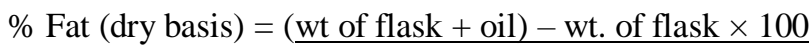
Weight of sample

\section{Crude fibre determination}

Two grams $(2 \mathrm{~g})$ of the sample from crude fat determination was weighed into a $750 \mathrm{ml}$ Erlenmeyer flask. Two hundred milliliters $(200 \mathrm{ml})$ of $1.25 \% \mathrm{H}_{2} \mathrm{SO}_{4}$ was added and immediately flask was set on hot plate and connected to the condenser. The contents were boiled within 1 minute of contact with solution. At the end of 30 minutes, flask was removed and immediately filtered through linen cloth in funnel and washed with a large volume of water. Filtrate (containing sample from

$\%$ Crude fibre $=\underline{\text { weight } \text { of crude fibre } \times 100}$

Weight of sample

$\%$ Crude fibre $=\underline{\text { wt }}$ of crucible + sample $($ before - after) ashing $\times 100$

Weight of sample

Where wt $=$ Weight of sample/spread

\section{Protein Determination \\ Digestion Method}

-bumping agents were added to the digestion

flask. Twenty five milliliters $(25 \mathrm{ml})$ of concentrated $\mathrm{H}_{2} \mathrm{SO}_{4}$ was added and the flask was shaken for the entire sample to become thoroughly wet. Flask was placed on digestion burner and heated slowly until boiling ceased and the resulting solution was clear. The sample was then cooled to room temperature and digested sample solution was transferred into a $100 \mathrm{ml}$ volumetric flask and made up to the mark. added to the round bottom flask and assembled the apparatus. A condenser was connected to the soxhlet extractor and reflux for 4-6 hours on the heating mantle. After extraction, thimble was removed and recovered solvent by distillation. The flask and fat/oil was heated in an oven at about $103^{\circ} \mathrm{C}$ to evaporate the solvent. The flask and contents were cooled to room temperature in a desiccator. The flask was weighed to determine weight of fat/oil collected.

acid hydrolysis) was washed and returned into the flask with $200 \mathrm{ml} 1.25 \% \mathrm{NaOH}$ solutions. Flask was connected to the condenser and was boiled for exactly 30 minutes. It was then filtered through Fischer's crucible and washed thoroughly with water and added $15 \mathrm{ml} 96 \%$ alcohol. Crucible and contents was dried for 2 hour at $105{ }^{\circ} \mathrm{C}$ and cooled in desiccator and it was weighed. Crucible was ignited in a furnace for 30 minutes and after that it was cooled and reweighed
Two grams (2g) of sample and a half of selenium -based catalyst tablets and a few anti

\section{Distillation Method}

To flush out the apparatus before use, distilled water was boiled in a steam generator of the distillation apparatus with the connections arranged to circulate through the condenser, for at least 10 minutes. The receiving flask was lowered and continued to heat for 30 seconds in order to carry over all liquid in the condenser. $25 \mathrm{ml}$ of $2 \%$ boric acid was pipetted into 
$250 \mathrm{ml}$ conical flask and 2 drops of mixed indicator added. The conical flask and its contents were placed under the condenser in such a position that the tip of the condenser is completely immersed in solution. $10 \mathrm{ml}$ of the digested sample solution was measured into the decomposition flask of the Kejdahl unit, fixed it and add excess of $40 \% \mathrm{NaOH}$ (about $15-20 \mathrm{ml}$ ) to it. The ammonia produced was distilled into the collection flask with the condenser tip immersed in the receiving flask till a volume of about $150 \mathrm{ml}-200 \mathrm{ml}$ is collected. Before distilling another sample and on completion of all distillations, the apparatus was flushed as in step 1 above. Steam was allowed to pass only until $5 \mathrm{ml}$ of the distillate is obtained.

\section{Titration Method}

The Distillate with $0.1 \mathrm{~N}$ HCL solution was titrated. The acid was added until the solution became colourless. Any additional acid added made the two solutions become pink. The nitrogen content was determined in duplicate, and a blank determination was run using the same amount of all reagents as used for

\section{Calculation}

Carbohydrate $(\%)=\%$ crude fibre $+\%$ NFE

OR

Carbohydrate $(\%)=100-(\%$ moisture $+\%$ fat $+\%$ protein $+\%$ ash $)$

x. Calculation for dry basis $=(100-\%$ moisture $) \times$ wet basis

100

\section{Sensory Analysis}

The sensory evaluation was done on three different samples: Sample A, B, and C. Fifty (50) consumers were randomly selected for the sensory. They were asked to evaluate the three coded samples on a 9-point hedonic scale with $1=$ like extremely, $2=$ like very much $3=$ like moderate, $4=$ like slightly, 5= Neither like nor dislike $6=$ dislike slightly, $7=$ dislike moderately, $8=$ dislike very much, $9=$ dislike extremely very much in an experiment for sensory evaluation on the sample. The blank was meant to correct for traces of nitrogen in the reagents and included digestion as well as distillation methods.

\section{Calculation}

$\%$ Total nitrogen $=\underline{100 \times(\mathrm{Va}-\mathrm{Vb}) \times \mathrm{NA} \times 0.01401 \times 100}$ $\mathrm{W} \times 10$

Where:

Va- volume in $\mathrm{ml}$ of standard acid used in titration $\mathrm{Vb}$ - volume in $\mathrm{ml}$ of standard acid used in blank NA- normality of acid W- Weight of sample taken

\section{Carbohydrate content}

The calculation of available carbohydrate (nitrogen-free extract-NFE) was made after completing the analysis for ash, crude fibre, ether extract and crude protein. The calculation was made by adding the percentage values on dry matter basis of these analysed contents and subtracting them from $100 \%$.

\section{RESULTS AND DiSCUSSION}

the parameters (colour, taste, mouth feel, flavour and overall acceptability).

\section{Statistical Analysis}

Data were analyzed using analysis of variance (ANOVA). Tukey Test was used to determine significant difference among the various samples in duplicate. Data were analyzed using the software, Statistical Package for Social Sciences (SPSS) version 22.00 (SPSS inc., Chicago), IL, USA at the 0.05 level of significance.

Table-2: Proximate analysis of the wheat and Bambara beans turnovers

\begin{tabular}{|l|l|l|l|l|l|}
\hline Samples & Moisture \% & Ash\% & Fat\% & Protein\% & Carbohydrate\% \\
\hline A & $18.93 \pm 0.43$ & $1.23 \pm 0.037$ & $31.02 \pm 1.47$ & $8.11 \pm 0.43$ & $40.62 \pm 185$ \\
\hline B & $19.33 \pm 0.47$ & $2.07 \pm 0.01$ & $30.41 \pm 0.21$ & $10.69 \pm 0.29$ & $37.51 \pm 0.96$ \\
\hline C & $18.34 \pm 0.22$ & $2.67 \pm 0.16$ & $34.75 \pm 0.78$ & $10.59 \pm 1.03$ & $33.65 \pm 0.31$ \\
\hline
\end{tabular}

Sample a (100\% wheat flour); Sample B (70\% wheat flour and 30\% Bambara beans flour); Sample C (50\% wheat flour and $50 \%$ Bambara beans flour)

(Source: Lab. Test, 2020)

\section{Moisture content}

The moisture content of the turnover ranged from 18.34-19.33\%. Sample B had the highest moisture content when compared with the control $(100 \%$ wheat flour). This could be due the addition of the Bambara beans flour or the percentage of the wheat flour blends which has been proven to have high affinity for moisture. The moisture contents of the samples were generally low. The low values are advantageous [15]. Reported that low moisture content is required to prevent growth of micro-organisms. 


\section{Ash content}

Ash is a non-organic compound containing mineral content of food and nutritionally its aids in the metabolism of the other compound. It was observed that the control sample (sample A $100 \%$ ) had $1.23 \%$ of ash content. However, the ash content (mineral) of the samples (B and C) increased from $2.07-2.67 \%$ with increase in the percentage $(30 \%$ and $50 \%)$ of the Bambara beans flour respectively. The high ash content of the products $\mathrm{A}$ and $\mathrm{B}(70 \%$ wheat flour and $30 \%$ Bambara beans flour) and Sample C (50\% wheat flour and $50 \%$ Bambara beans flour)) could be an indication of an increase in the mineral content as reported by [15]. A similar result was also reported by [16].

\section{Fat content}

The fat content increased from 30.41-34.21\% with an increase in the percentages of Bambara beans flour of (30-50\%). The increase in fat content could be due to the quantity of Bambara beans flour used. The high fat content could cause rancidity to the products. The increase in the fat content could be a good source of energy to human body. It was observed that the control had the lowest fat content

\section{Protein content}

The crude protein content of the samples ranged from $8.11-10.69 \%$. Sample A (control) had the lowest protein content of $8.11 \%$ while sample B $(70 \%$ wheat flour and 30\% Bambara beans flour) had the highest value of $10.69 \%$ followed by sample C $(50 \%$ wheat flour and $50 \%$ Bambara beans flour). There was a significant $(\mathrm{p}<0.05)$ difference between the fortified samples and the control due to the variations of Bambara bean flour incorporated into the wheat flour. This was predictable because Bambara bean is a legume while wheat is a cereal grain. Obviously, legumes contain more protein than cereals, though, the predominant protein in wheat happens as gluten which is needed in baking. The high crude protein content of Bambara bean flour generally establishes the usual protein complements to the staple food. This agrees with the work of [17], who supplemented the crude protein content of "Ojojo" and cookies using rice-bean flours and African yam bean seeds respectively.

\section{Carbohydrate}

The control samples (100\% wheat flour) had the highest carbohydrate content of $40.62 \%$. The fortified samples had carbohydrate content ranged from $37.51 \%$ and $33.65 \%$ respectively. The decreased in carbohydrate content could be due to the low carbohydrate content in the Bambara beans flour.

Table-3: The sensory analysis of the turnovers

\begin{tabular}{|l|l|l|l|l|l|l|}
\hline Samples & Colour & Texture & Aroma & Taste & Aftertaste & Level of acceptability \\
\hline A & $5.23 \pm 0.80$ & $4.10 \pm 0.93$ & $4.3 \pm 0.80$ & $3.10 \pm 0.70$ & $4.00 \pm 0.50$ & $4.02 \pm 0.70$ \\
\hline B & $4.32 \pm 0.70$ & $3.20 \pm 0.80$ & $5.00 \pm 0.10$ & $5.20 \pm 0.60$ & $4.12 \pm 0.80$ & $5.20 \pm 0.70$ \\
\hline C & $4.10 \pm 0.80$ & $3.9 \pm 80$ & $3.50 \pm 0.80$ & $2.50 \pm 0.90$ & $3.7 \pm 0.60$ & $3.40 \pm 0.90$ \\
\hline LSD & 0.23 & 0.342 & 0.021 & 1.481 & 0.0126 & 0.061 \\
\hline
\end{tabular}

(Source: field survey, 2020)

Sample a (100\% wheat flour); Sample B (70\% wheat flour and 30\% Bambara beans flour); Sample C (50\% wheat flour and 50\% Bambara beans flour)

\section{Colour}

Colour is a sensory quality that consumers discover in purchasing new products due to its visual appeal. Mostly, it refers to the appearance of the product. The colour of the turnovers samples ranged from $4.10-5.23 \%$ with the control sample A (100\% wheat flour) having a high mean score while the least mean score was sample C $(50 \%$ wheat flour and $50 \%$ Bambara beans flour). There was a significant $(\mathrm{p}<0.05)$ difference between the composite sample B $(70 \%$ wheat flour and 30\% Bambara beans flour) and the control (100\% wheat flour). This colour difference could be attributed to the whole wheat flour used in the preparation of the turnovers without addition of any composite flour.

\section{Texture}

It was observed that the texture of the control sample (100\% wheat flour) had the highest mean score of approximately 4.10 that is" liked very much". It was also observed that, sample B had the least mean score of 3.20. However, at $\mathrm{P}<0.05$ level of probability revealed that there was no significant difference between the $100 \%$ wheat flour turnover and the composites ones which were also moderately liked according to the hedonic scale measures. This implies that, turnovers produced per this study have its hardness very satisfactory.

\section{Aroma}

Another feature that influences the acceptance of baked products is the aroma. The composite turnover sample B $(70 \%$ wheat flour and 30\% Bambara beans flour) had the highest score of 5.0 that is "liked extremely", followed by sample A with a score of 4.0 and Sample $\mathrm{C}$ had the lowest mean score rating according to the respondents with the score of approximately 3.0. It was observed from the result that there was a significant $(p>0.05)$ between the composite samples and the control of the aroma of the samples as $30 \%$ of the Bambara bean flour was incorporated. This increase may be attributed to the flavour from Bambara 
bean flour with which the turnovers were fortified, which is quite different from the usual turnovers that are produced solely from wheat flour.

\section{Taste}

Taste refers to impression professed by the tongue which comprises sweet, salty, sourness and bitterness [18] (Potter and Hotchkiss, 1996). This is conversely inclined by the quality of the raw materials used in the preparation of the turnovers. The taste of the turnover samples ranged from 5.20-2.50 with the highest mean score being sample B $(70 \%$ wheat flour and $30 \%$ Bambara beans flour). This observation proves that both samples B were much accepted in terms of taste. However, there was a significant $(p<0.05)$ different between the composite samples and the control.

\section{Aftertaste}

Aftertaste had the mean scores varying from 3.7-4.12 as $30 \%$ of the Bambara bean flour was used partly to replace the whole wheat flour. It was observed that sample B had the highest score (4.12) while sample $\mathrm{C}$ had the least score (3.70). Also, there was significant $(\mathrm{p}<0.05)$ difference between sample B $(70 \%$ wheat flour and 30\% Bambara beans flour) and the control, but there was a significant $(\mathrm{p}>0.05)$ difference between the control sample A (100\% wheat flour) and the composite sample $\mathrm{C}$ as the level of the Bambara bean flour increased.

\section{Overall acceptability}

The quality of the turnovers (Aroma, colour, texture and taste) had influence the overall acceptability of the turnovers. There was a significant $(p<0.05)$ difference between all fortified samples and the control sample. Sample B (70\% wheat flour and 30\% Bambara beans flour) had the highest mean score (5.2) followed by sample A (100\% wheat flour). Sample a $(100 \%$ wheat flour) had the mean score of (4.0) that is "liked very much" and sample $\mathrm{C}$ had the lowest scores of mean score of 3.0 that is liked moderately. Sample B was the most accepted followed by samples A.

\section{CONCLUSION}

The results from the study indicate that Bambara beans flour can be used to produce quality turnovers without any effects on the nutritional and sensory attributes of the products. Moreover, Bambara beans flour can be used as a substitute with wheat flour up to $30 \%$ level in production of turnovers. Turnover made with $(70 \%$ wheat flour and $30 \%$ Bambara beans flour) substitutions was accepted by the respondents.

\section{REFERENCES}

1. Nwosu, J. N. (2013). Production and evaluation of biscuits from blends of Bambara Groundnut (Vigna Subterranae) and Wheat (Triticum Eastrum) flours. International journal of food and nutrition science, 2(1), 4-9.

2. Akpalu, M. M., Atubilla, I. A., \& Oppong-Sekyere, D. (2013). Assessing the level of cultivation and utilization of bambara groundnut (Vigna subterranea (L.) Verdc.) in the Sumbrungu community of Bolgatanga, Upper East Region, Ghana. International Journal of Plant, Animal and Environmental Sciences, 3(3), 68-75.

3. Bamshaiye, O. M., Adegbola, J. A., \& Bamishaiye, E. I. (2011). Bambara groundnut: an under-utilized nut in Africa. Advances in agricultural biotechnology, 1(1), 60-72.

4. Uvere, P. O., Uwaegbute, A. C., \& Adedeji, E. M. (1999). Effects of malting on the milling performance and acceptability of bambara groundnut (Voandzeia subterranea Thouars) seeds and products. Plant Foods for Human Nutrition, 54(1), 49-57.

5. Linnemann, A. R. (1987). Bambara groundnut (Vigna subterranea (L.) Verdc.): a review. In Abstracts on Tropical Agriculture (Vol. 12, No. 7, pp. 9-25).

6. Aykroyd, W. R., Doughty, J., \& Walker, A. F. (1982). Legumes in human nutrition (Vol. 20). Food \& Agriculture Org.

7. Brough, S. H., \& Azam-Ali, S. N. (1992). The effect of soil moisture on the proximate composition of Bambara groundnut (Vigna subterranea (L) Verdc). Journal of the Science of Food and Agriculture, 60(2), 197-203.

8. Ibrahin, H. D., \& Ogunwusi, A. A. (2016). Industrial potentials of Bambara nut. Journal of Poverty, Investment and Development, 22, 12-16.

9. Shewry P.R, Powers, S., Field, J.M, Fido, R. J, Jones, H.D., Arnold, G.M., West, J., Lazzeri, P.A., Barcelo, P., Subhadhirasakul, S., Yuenyoungsawwad, S., Ketjinda, W., Phadoongsombut, N., \& Faroong-Sarng, D. (2001). Study on tablet binding and disintegration properties of alternate starches prepared from taro and sweet potato tubers. Drug Development and Industrial Pharmacy, 27, 81-87.

10. Kumar, P., Yadava, R. K., Gollen, B., Kumar, S., Verma, R. K., \& Yadav, S. (2011). Nutritional contents and medicinal properties of wheat: a review. Life Sciences and Medicine Research, 22, 1-10.

11. Zouari, R., Besbes, S., Ellouze-Chaabouni, S., \& Ghribi-Aydi, D. (2016). Cookies from composite wheat-sesame peel flours: Dough quality and effect of Bacillus subtilis SPB1 biosurfactant addition. Food chemistry, 194, 758-769.

12. Foskett, D., \& Cesarani, V. (2007). Food Safety. In Foskett, D. and Cesarani, V. (Eds). The Theory of Catering, p. 631-638. London: Hodder Education.

13. AOAC. (2000). Official methods of analysis. 17th ed The Association of Official Analytical Chemists, Arlington, VA. 
14. Association of Official Analytical Chemists. (2005). A. O. A. C. No. 2003.05 and No. 2001.11. Chapter 4. Official Methods of Analysis. 18th ed.

15. Wachukwu, C. K., Sokari, T. G., \& Wemedo, S. A. (2003). Effects of sun drying and smoking on Salmonella typhimurium (LT 2) during cowpeadaddawa processing. Plant Foods for Human Nutrition, 58(3), 1-7.

16. Akpapunam, M. A., \& Darbe, J. W. (1994). Chemical composition and functional properties of blends of maize and bambara groundnut flours for cookie production. Plant Foods for Human Nutrition, 46(2), 147-155.

17. Okoye, E. C., \& Onyekwelu, C. N. Production and quality evaluation of enriched cookies from wheat, african yam bean and carrot composite flours.

18. Potter, N.N., Hotchkiss, J.H. (1996). Food Science (5/e). CBS Publisher and Distributors, New Delhi. 